\title{
Successful local marine conservation requires appropriate educational methods and adequate enforcement
}

\author{
G.J. Watson, J.M. Murray, M. Schaefer, A. Bonnerd
}

\begin{abstract}
MPAs and stakeholder education are marine conservation cornerstones, but data to assess adherence to regulations and the success of educational methods are missing. Local MPAs have been established to protect inter-tidal mudflats and shore users from bait collection which is a contentious worldwide issue. Video cameras monitored activity and confirmed if collectors adhered to the rules at three UK sites with different MPA systems. An educational approach (a voluntary code leaflet) was also assessed through stakeholder discussion and observation. Fareham Creek and Dell Quay supported a considerable number of collectors with none observed at Pagham Harbour. At Fareham Creek bait dug areas were evident in discrete patches in unprotected and protected areas, but observed collectors mainly used the latter. The failure to exclude collectors is due to the lack of enforcement. At Dell Quay virtually all dug areas were outside protected areas and was confirmed by the camera footage. Success is attributed to regular on-theground 'unofficial' enforcement by the managing NGO. Of the retailers, $75 \%$ had heard of the code and the majority stated they followed it. However, none of the 26 collectors observed followed a key rule (e.g. backfilling holes). Local marine conservation is relatively cheap and can be effective, but only if: management matches the actual pressure; scientific evaluation for all components (including education) is integrated from the beginning; adequate site enforcement is included; education methods are active, twoway and sustained.
\end{abstract}

\section{Introduction}

\subsection{MPAs as conservation tools}

Marine protected areas (MPAs) are now the major focus of marine conservation with over 5000 areas identified in 2010 [23]. Sizes range from $0.001 \mathrm{~km}^{2}$ to $640,000 \mathrm{~km}^{2}$ [37] and a recent global assessment has confirmed that size is a critical requirement of success [13]. Globally the mean size of MPAs is $544 \mathrm{~km}^{2}$, however, a more detailed investigation confirms that approximately 1200 are less than $1 \mathrm{~km}^{2}$ and another 1400 are less than $10 \mathrm{~km}^{2}$ [40]. The majority of MPAs are, therefore, small in extent and defined as 'local' by Pressey et al. [28]. Economic drivers and the devolution of power down to communities mean that local partnerships are often preferred by government [30], so local MPAs will usually have been established and managed by locally-focussed organisations. 
[13], amongst many others, highlighted the requirement of enforcement for MPA success. However, direct studies on enforcement are extremely limited. Ceccherelli et al. [8] used site accessibility as a proxy for human activity, but did not measure activity directly. Guidetti et al. [18] and Sala et al. [32] grouped reserves into three levels of enforcement, but again did not measure the actual levels of adherence. The impact of illegal fishing in MPAs for a temperate invertebrate fishery was recently investigated, however, the assessment was initially not quantitative and then pseudoreplicated [24]. No study has, therefore, used empirical field data to assess adherence to local MPA regulations.

Often associated with local MPAs is the inclusion of stakeholder education [29], which in all its diverse forms (e.g. face-to-face discussions, workshops, leaflets, websites, notice boards etc) is seen as a vital tool in protecting biodiversity and can change people' $s$ attitudes [17] and [9]. There is a long history of educational material to support local marine conservation and MPAs, and although many MPAs have an integrated educational strategy (e.g. [29] and [19]), few (e.g. [21]) have empirically assessed the educational and outreach response, leading Cooke et al. [10] to highlight an urgent need to assess compliance to (success of) educational or voluntary codes of conduct.

\subsection{Case study: Bait collection}

Invertebrate species are increasingly exploited for fisheries with a dramatic rise in catch levels in recent decades [4]. The risks of over exploitation and the consequences to the ecosystems are, therefore, significant. Bait collection is the harvesting of organisms for use as bait for angling and has been an integral part of coastal life for generations. Accurate assessments of the industry are lacking, but with up to $2 \%$ of all adults in England going sea fishing [5] and more worldwide it is a substantial component of many coastal economies [26], [16], [11] and [36]. The vast majority of these people will rely on wild-collected bait, but it is a highly contentious issue (it remains a UK public right to collect bait for personal use, but not commercially). This results in the polarisation of collectors and those managing marine resources and the associated coastal communities. Ragworms (e.g. Nereis [Alitta] virens) are a major group collected by digging with a fork and the impacts on sediments, benthic communities, birds and shore users have received considerable attention (e.g. [3], [15], [33] and [38]).

European Marine Sites are set up to manage marine and coastal resources in a sustainable way; their aim is to enable already established activities to continue, but in ways that do not threaten the nature conservation interest. The Solent region European Marine Site (SEMS) contains a number of internationally important MPAs designated under the EU Directives as Special Areas of Conservation (SACS) and Special Protection Areas (SPAs) as well as Ramsar sites and local nature reserves. Inter-tidal mud flats are key habitats for SACs and many SPAs recognise this habitat as an important sub-feature for birds. However, the SEMS is utilised by approximately 40,000 active sea anglers [16] and has extensive soft sediment, which gives great scope for exploitation of this resource for bait. Surprisingly, EMS-level designations have not 
been employed to manage bait collection. Instead, management has been devolved to the local level through specific byelaws combined with educational methods to protect the inter-tidal mud flats and the associated birds that utilise them. This has resulted in a range of local site-specific management strategies that are running concurrently and are in close proximity to each other.

1.3. Local management

Fareham Creek is a key bait collection area within the Portsmouth Harbour SPA [16]. An additional MPA (a Special Nature Conservation Order [SNCO]) to protect inter-tidal areas has been in force since 2003/4 with commercial collection within the area prohibited (Fig. 1). Dell Quay in Chichester Harbour is also important [16], but it contains a large number of intertidal moorings and jetties used by recreational boat-users.

Consequently the local NGO implemented an MPA with a byelaw to prohibit bait collection within $15 \mathrm{~m}$ of any mooring or $6 \mathrm{~m}$ of any structure to protect vessels and moorings and to minimise the risk of injury (Fig. 2). Pagham Harbour is a Local Nature Reserve and SPA and a recently designated Marine Conservation Zone located at the east end of the Solent. An additional level of management was established involving zonation and licensing, and managed by the local management organisation. Only those who hold an annual permit are able to collect bait and there is also a bag limit of $0.5 \mathrm{~kg}$ per visit. Collection is restricted to two areas with access to Zone B from 1st April to 31st August and access to Zone A from 1st September to 31st March (Fig. 3). 


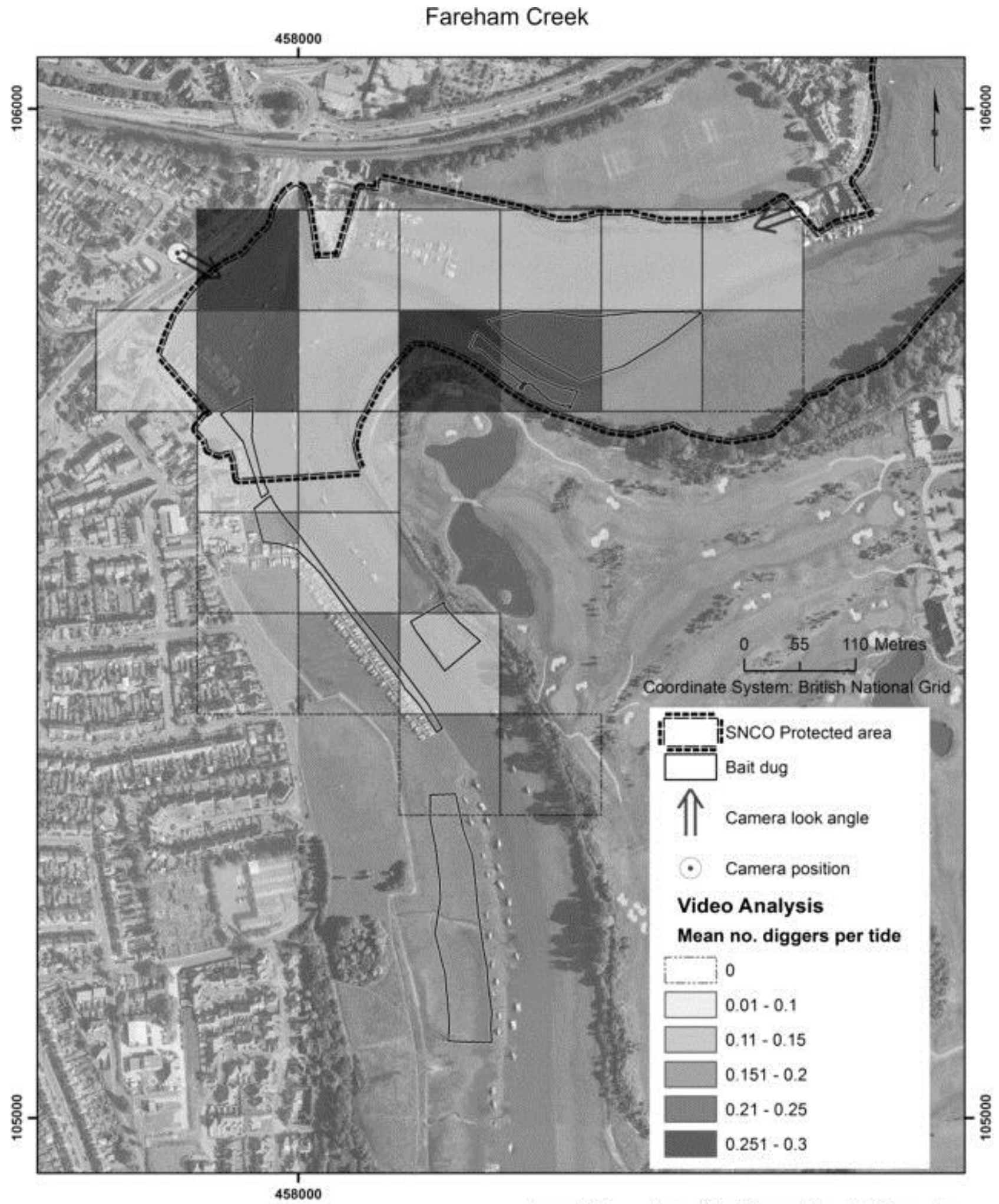

Image Data courtesy of the Channel Coastal Observatory http://www.channelcoast.org/

Fig. 1.

Map of Fareham Creek (Portsmouth Harbour) showing mean number of collectors per hectare per tide. Data are from both runs combined and include night and day tides and all activities performed by the collectors (digging and walking). Those squares with no colour had no recorded activity. Bait dug areas mapped during the biotope walkover are outlined in black. Commercial bait collection is not permitted in the outlined area (within the SNCO). The camera positions and directions of fields of view are denoted by arrows. 


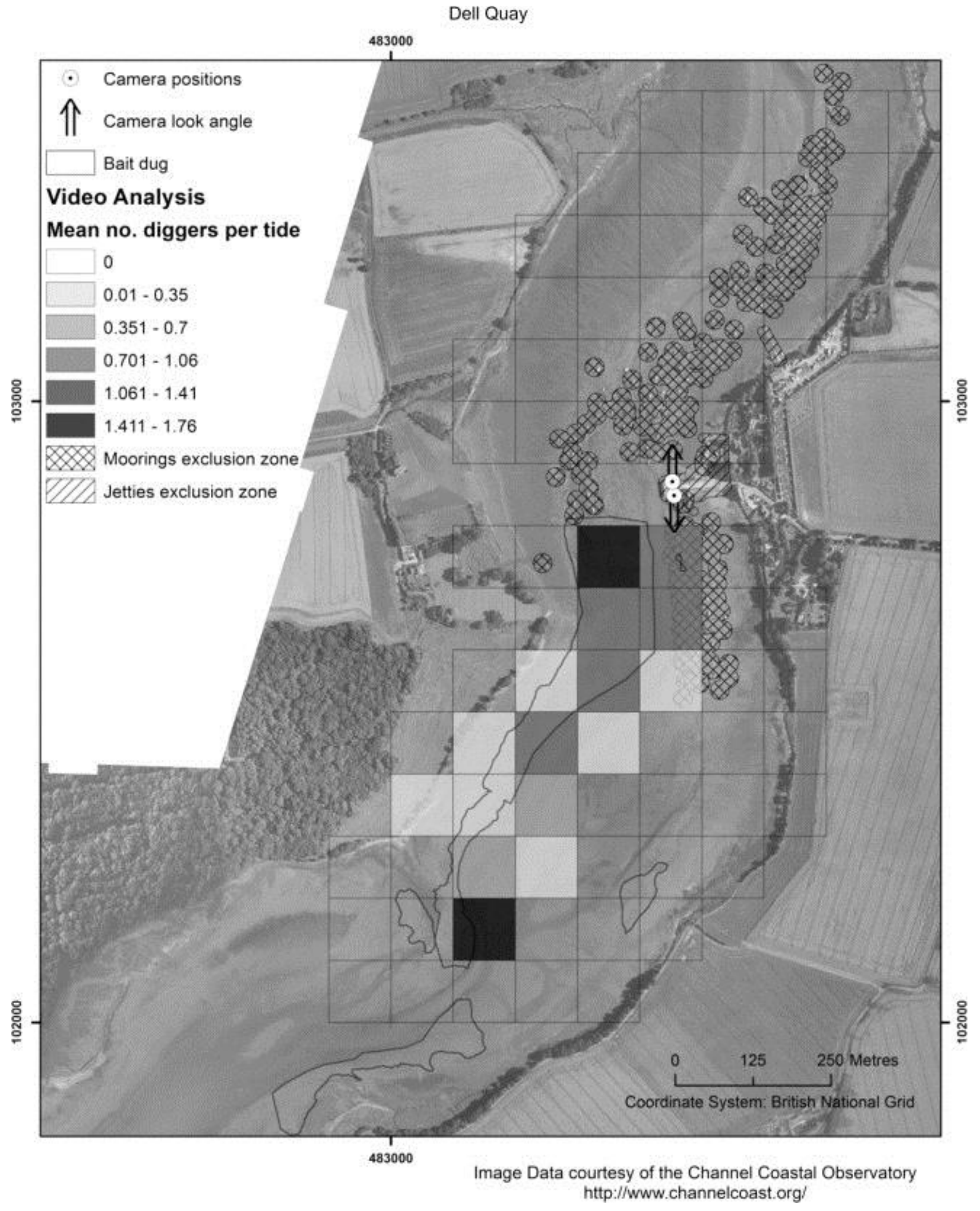

Fig. 2.

Map of Dell Quay (Chichester Harbour) showing mean number of collectors per hectare per tide. Data are from both video runs combined and include night and day tides and all activities performed by the collectors (digging, walking and boating). Those squares with no colour had no recorded activity. Bait dug areas mapped during the biotope walkover are outlined in black. Exclusion zones for moorings and quays, jetties are shown with cross hatching. The camera positions and directions of fields of view are denoted by arrows. 


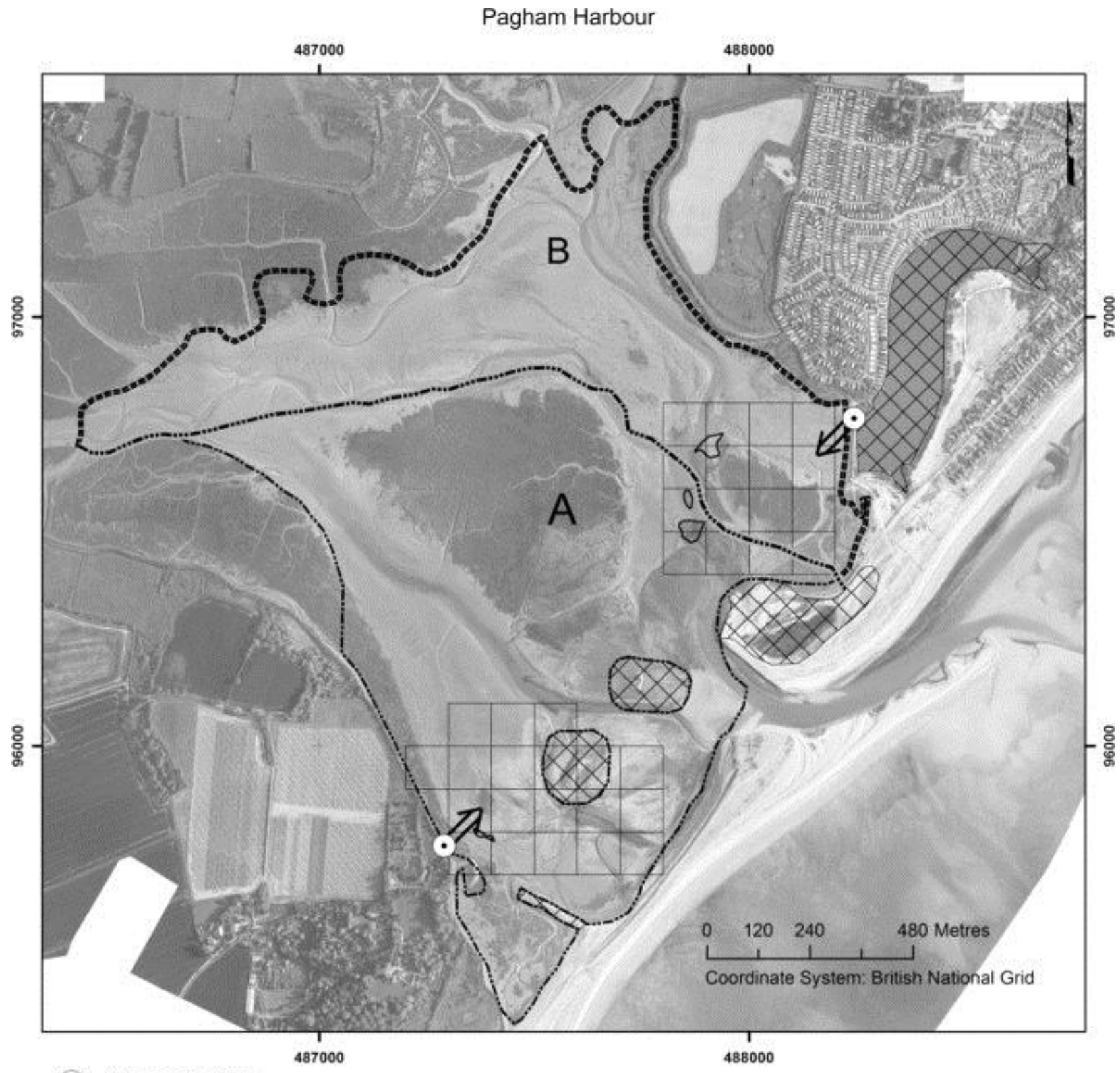

- Camera position

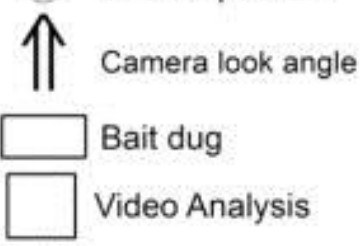

Image Data courtesy of the Channel Coastal Observatory http I/www.channelcoast.org/

\section{Protected areas}

Permit Area A No Access from 1st April to 31st August - Fishing, Bait Digging and Boating
Permit Area B No Access from 1st September to 31st March - Fishing and Bait Digging
A/B Boundary
No Access at Any Time

\section{Fig. 3.}

Map of Pagham Harbour. Bait dug areas mapped during the biotope walkover are outlined in black. Bait collection is not permitted in area A between 1st April and 31st August and not permitted in area B between 1st September and 31st March. Only those who hold an annual permit are able to collect bait $(0.5$ $\mathrm{kg}$ limit per visit). The camera positions and directions of fields of view are denoted by arrows. 
Fowler [16] was the first to propose the use of a voluntary code of conduct to minimise the impacts of bait collection through education. The code was developed by local stakeholders and includes ten points, although only five relate directly to the impacts and sustainability of bait collection (Table 1); the others cover general shore awareness/safety. A working group was established within the local management authority and posters and 42,000 leaflets were produced to maximise exposure.

Table 1.

Extract of the Bait Collectors' Code including a summary of the key statements (and details of each) relating to reducing the impacts of bait collection.

\begin{tabular}{|l|l|}
\hline Main point & Detail \\
\hline 1. Observe local byelaws and regulations & Only dig in those permissible areas \\
\hline \multirow{2}{*}{ 2. Collect bait in a sustainable fashion } & $\begin{array}{l}\text { Avoid damaging other animals, take only what is } \\
\text { necessary }\end{array}$ \\
\cline { 2 - 2 } & Do not take spawning worms \\
\cline { 2 - 2 } & Store bait correctly to minimise mortality \\
\cline { 2 - 2 } & Return unused bait to similar areas \\
\hline 3. Back-fill holes & For safety and to maintain inter-tidal habitat \\
\hline $\begin{array}{l}\text { 4. Avoid disturbing wildlife and marine } \\
\text { heritage }\end{array}$ & Including birds and marine mammals \\
\hline $\begin{array}{l}\text { 5. Do not dig near moorings, slipways or sea } \\
\text { walls }\end{array}$ & \\
\hline
\end{tabular}

Using a novel assessment method (remote Closed Circuit Television [CCTV] cameras) to record and quantify bait collection activity, the efficacy of the three local MPAs established to manage bait collection has been evaluated. Retail surveys (angling shops) have provided a direct assessment of the awareness of the voluntary code of conduct and stakeholders' compliance, whilst field-based CCTV observations have provided quantitative data on the level of adherence to the code.

\section{Materials and methods}

\subsection{Mapping the extent of bait collection}

Sites were surveyed over spring tides in August and September 2011 with surveying happening approximately three hours either side of low tide. A biotope survey assessment of the sites was conducted and bait collected areas mapped using Differential Global Positioning System (DGPS) (approximately $10 \mathrm{~cm}$ accuracy), in conjunction with hand-drawings of habitat boundaries on aerial photographs (scale 1: 10,000). Points were recorded by walking along the outer boundary of dug areas and any polygons considered too small to be mapped with DGPS, were numbered on the aerial photograph. Bait dug areas matched in the field were then digitised in GIS (ArcGIS 10.2.2). 


\subsection{CCTV installation and video analysis}

Two Sanyo HD 4600 cameras with external hard-drives were used for direct recording and were rotated among the sites. The cameras at Dell Quay were located inside a building to face north and south (Fig. 2). At Fareham Creek cameras were placed in Residents' houses giving coverage of the lower part of the SNCO and the adjacent sediment outside (Fig. 1). Cameras at Pagham Harbour were sited to monitor areas known to be used for bait collection (Fig. 3). Cameras were set up twice at each site during 2011 and 2012 with the expectation that they would record continuously for one tidal cycle (approximately 14 days) for each run. However, battery failure and other circumstances meant that some periods were not recorded (see Table 2 for details).

Table 2.

Details of video recordings from each site including number of tides analysed and any missing times. Three hours per tide were analysed ( $1 \mathrm{~h}$ before low tide and $2 \mathrm{~h}$ after).

\begin{tabular}{|c|c|c|c|c|c|c|}
\hline Run & Site & $\begin{array}{l}\text { Camera } \\
\text { location }\end{array}$ & Run duration & $\begin{array}{l}\text { Missing dates } \\
\text { (low tide time) }\end{array}$ & Reasons & $\begin{array}{l}\text { Number of } \\
\text { tides analysed }\end{array}$ \\
\hline 1 & Dell Quay & $\begin{array}{l}\text { North- } \\
\text { facing }\end{array}$ & $\begin{array}{l}17 / 08 / 11- \\
1 / 09 / 11\end{array}$ & - & - & 29 \\
\hline 1 & Dell Quay & $\begin{array}{l}\text { South- } \\
\text { facing }\end{array}$ & $\begin{array}{l}17 / 08 / 11- \\
1 / 09 / 11 \\
\end{array}$ & $28 / 8(16: 52)$ & $\begin{array}{l}\text { Camera not } \\
\text { working }\end{array}$ & 28 \\
\hline 2 & Dell Quay & $\begin{array}{l}\text { North- } \\
\text { facing }\end{array}$ & $\begin{array}{l}\text { 9/11/11- } \\
21 / 11 / 11\end{array}$ & - & - & 25 \\
\hline \multirow[t]{2}{*}{2} & \multirow[t]{2}{*}{ Dell Quay } & \multirow[t]{2}{*}{$\begin{array}{l}\text { South- } \\
\text { facing }\end{array}$} & \multirow[t]{2}{*}{$\begin{array}{l}9 / 11 / 11- \\
21 / 11 / 11\end{array}$} & $17 / 11(20: 47)$ & $\begin{array}{l}\text { Lights in } \\
\text { room }\end{array}$ & \multirow[t]{2}{*}{23} \\
\hline & & & & 19/11 (10:33) & Blind down & \\
\hline 1 & $\begin{array}{l}\text { Fareham } \\
\text { Creek }\end{array}$ & Resident 1 & $\begin{array}{l}\text { 5/9/11- } \\
\text { 18/9/11 }\end{array}$ & - & - & 26 \\
\hline 1 & $\begin{array}{l}\text { Fareham } \\
\text { Creek }\end{array}$ & Resident 2 & $\begin{array}{l}10 / 9 / 11- \\
23 / 9 / 11\end{array}$ & - & - & 25 \\
\hline 2 & $\begin{array}{l}\text { Fareham } \\
\text { Creek }\end{array}$ & Resident 1 & $\begin{array}{l}11 / 12 / 11- \\
24 / 12 / 11 \\
\end{array}$ & - & - & 30 \\
\hline 2 & $\begin{array}{l}\text { Fareham } \\
\text { Creek }\end{array}$ & Resident 2 & $\begin{array}{l}11 / 12 / 11- \\
24 / 12 / 11\end{array}$ & - & - & 30 \\
\hline \multirow[t]{2}{*}{1} & \multirow[t]{2}{*}{$\begin{array}{l}\text { Pagham } \\
\text { Harbour }\end{array}$} & \multirow[t]{2}{*}{ East-facing } & \multirow[t]{2}{*}{$\begin{array}{l}20 / 1 / 12- \\
2 / 2 / 12\end{array}$} & $27 / 1(19: 37)$ & $\begin{array}{l}\text { Battery ran } \\
\text { out }\end{array}$ & \multirow[t]{2}{*}{24} \\
\hline & & & & $28 / 1(07: 54)$ & $\begin{array}{l}\text { Battery ran } \\
\text { out }\end{array}$ & \\
\hline 1 & $\begin{array}{l}\text { Pagham } \\
\text { Harbour }\end{array}$ & West-facing & $\begin{array}{l}20 / 1 / 12- \\
2 / 2 / 12\end{array}$ & - & - & 20 \\
\hline \multirow[t]{3}{*}{2} & \multirow[t]{3}{*}{$\begin{array}{l}\text { Pagham } \\
\text { Harbour }\end{array}$} & \multirow[t]{3}{*}{ East-facing } & \multirow[t]{3}{*}{$\begin{array}{l}24 / 7 / 12- \\
7 / 8 / 12\end{array}$} & $30 / 7(15: 26)$ & $\begin{array}{l}\text { Battery ran } \\
\text { out }\end{array}$ & \multirow[t]{3}{*}{15} \\
\hline & & & & $31 / 7(04: 00)$ & $\begin{array}{l}\text { Battery ran } \\
\text { out }\end{array}$ & \\
\hline & & & & $31 / 7(16: 25)$ & $\begin{array}{l}\text { Battery ran } \\
\text { out }\end{array}$ & \\
\hline 2 & $\begin{array}{l}\text { Pagham } \\
\text { Harbour }\end{array}$ & West-facing & $\begin{array}{l}24 / 7 / 12- \\
7 / 8 / 12\end{array}$ & - & - & 17 \\
\hline
\end{tabular}


Video starting one hour before the predicted low tide time from the nearest tidal station until two hours after low tide was viewed during which time the number and location of collectors were recorded. A one hectare grid was overlaid on the aerial view of each site and the time spent by each collector (digging, walking and boating) in each hectare recorded. Both day and night tides were analysed as collecting is only dependent on the tide. Although the cameras have near-infrared capability and can record in low light conditions, records of activity in the dark were reliant on a collector's head torch. If this made the precise location of the collector difficult to ascertain data were excluded from any spatial analysis. Low tides were also assigned to one of three categories (occurring in the dark, light or both [e.g. dawn or dusk]) and the percentage number of tides in these categories with collectors calculated. Correspondence with the UK Government's Information Commissioner's Office confirmed that personal data legislation did not apply to the collected images.

\subsection{Educational evaluation}

As the majority of bait purchased is from retailers and it is also estimated that $75 \%$ of anglers are not affiliated to any angling association [15] the most appropriate way of assessing the code was to visit coastal fishing shops. In addition, approaching collectors on the shore is often seen as confrontational and results in a lack of engagement (G.J.W., personal observation). To prevent the questionnaire becoming interrogative there was no formal discussion structure, but notes were taken and a series of questions were broached:

(a) Have they heard of the code (leaflet was shown to interviewee)?

(b) Do they, or the collectors who supply them, follow it?

(c) Has it made a difference to bait collection management?

(d) What else could be done to improve the management in the future?

To assess the level of infringement, collectors were recorded from three view points at Dell Quay and two at Fareham Creek between November 2012 and March 2013. Only daylight tides were utilised and the cameras were focussed on areas already shown to support significant collection from the earlier video analysis. Videos were analysed to see if collectors back-filled holes (defined as complete filling of the dug hole with dug sediment).

\section{Results}

All activity at Dell Quay occurred south of the quay with the mean number of collectors recorded per tide as 3.14 (SD 3.51) within the $0.48 \mathrm{~km} 2$ covered by the camera, although there was considerable variation between tides and dates (runs). Specific areas were favoured by the collectors indicated by the hectares with a high number of collectors per tide (Fig. 2). Many individuals dug very close to the quay, but some either walked or rowed to the southern edge of the mapped area. The vast majority of the recorded dug 
sediment occurred outside of the protected zones, although there were small patches of overlap close to the quay. Confirmation of this adherence is also shown by the distribution of collector activity (Fig. 2) and the video footage with significantly more collection (mean number of collectors per tide) occurring in the unprotected areas (Wilcoxon signed rank test, W51=496, p=0.000) (Fig. 4).

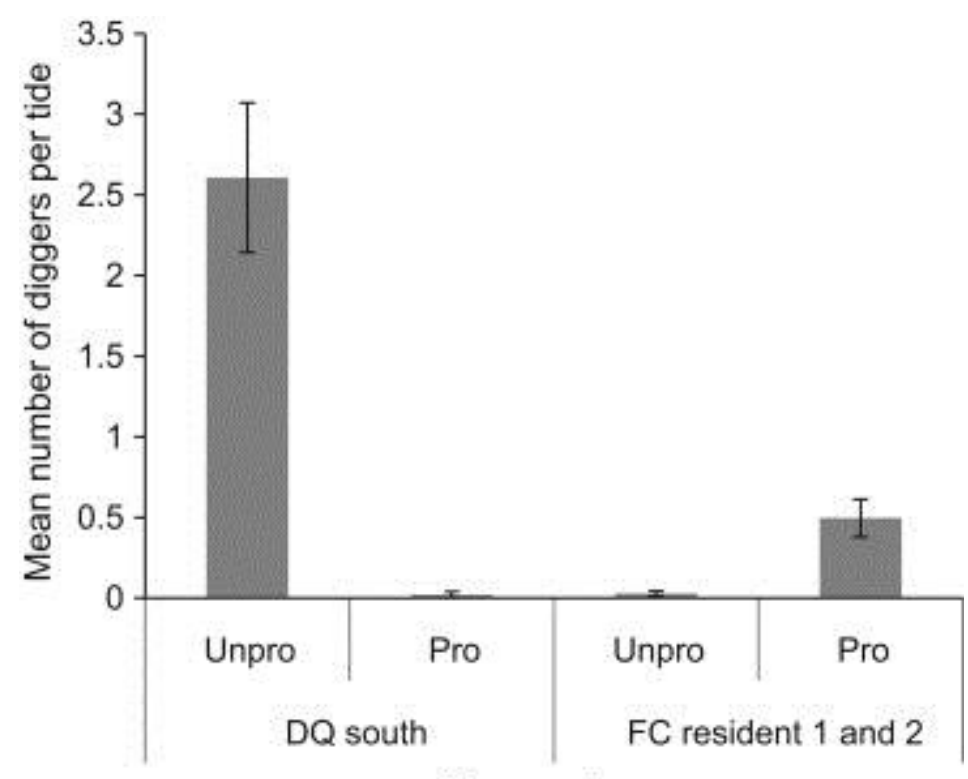

\section{Camera view}

Fig. 4.

Mean number of collectors (SE) per tide recorded from the video footage designated as collecting inside the unprotected or protected areas (exclusion zones around moorings, jetties and quays) at Dell Quay (DQ) and outside or inside the SNCO (protected area) at Fareham Creek (FC) for Resident 1 and 2's combined camera view.

Fewer collectors per tide were recorded at Fareham Creek when compared to Dell Quay, but with slightly more from Resident 2's view (0.78, SD 1.5) than Resident 1's (0.38, SD 1.1. Again, variation between tides and runs was also high. Two main areas were utilised with all locations accessed by walking across the sediment or along the channel (Fig. 1). Bait dug areas were in discrete patches in the protected (within the SNCO) and unprotected areas in the low to mid shore areas. However, analysis of the video footage would indicate that the activity was mainly confined to within the SNCO with a highly significant difference in the mean number of collectors per tide between the protected and unprotected area for Resident 1 and 2's view combined (W111=11, $\mathrm{p}=0.000$ ). Dug areas were also recorded at Pagham Harbour, but the patches were very small and all except one were in the area where collecting is prohibited from September to March (Fig. 3). No collectors were seen over the area covered $(0.35 \mathrm{~km} 2)$ during the tides analysed.

The vast majority of recorded collecting occurred during the day or at dawn and dusk. No collectors were recorded at Fareham Creek when the three hour low tide recording period was in the dark, but four tides (an early morning in August, and two early evening and one early morning in November) equating to $27 \%$ of the observed dark tides were used for Dell Quay. 


\subsection{Education and the bait collectors' code}

Nineteen angling stores were visited during August 2012 with one store contacted by phone and all were happy to discuss the code. When mentioned or shown a copy, $75 \%$ of the shops had heard of the code. Although 15 out of the 17 who said that they, or the collectors who collect for them, followed it, four of these stores had originally said they had not heard of it. Comments on lack of adherence were grouped into two main opposing themes: those who said that it was a specific type of commercial collector (i.e. collectors paid in cash) who did not adhere to the code and those who said that it was the casual (i.e. holiday) angler. The lack of back-filling holes was mentioned a number of times. It was more difficult to get a clear response about how the code was working, only three stores stated explicitly that it was working well, with another four saying that it wasn't. Suggestions to improve management included: education, rotation of stock areas and a licensing system for commercial collectors, although many also highlighted the drawbacks of these approaches. From the targeted video recordings (1316 min of digging) data for an estimated 26 collectors were recorded during this period, with none observed back-filling their holes.

\section{Discussion}

\subsection{Bait collection at the sites}

The three sites assessed in this study were chosen because they already had local management established, however it is clear that the sites had very different levels of bait collection with Dell Quay the most popular and Fareham Creek much more popular than Pagham Harbour. An obvious reason for these differences is the density of $\mathrm{N}$. virens as shown by Watson et al. [38], but other important factors include shore access and distance to collection areas. Both Dell Quay and Fareham Creek have close easy-access areas. The absence of collectors during the two recording periods at Pagham Harbour is surprising considering the number of permitted collectors. It is possible that management at this site may be having a deterrent effect, however, a much more plausible reason is the difficulty of access (distance to the Harbour and from car parks to the sediment) that deters all except local people.

\subsection{Are MPA rules adhered to?}

Our data show that the management methods differ in their ability to ensure collectors adhere to the rules. At Dell Quay the byelaw excluding digging around moorings etc has been very successful. Apart from a small area of mapped dug sediment and one bait collector spending $12 \mathrm{~min}$ in the protected area, all other collection activity was located in unprotected areas. Signage detailing the rules of the byelaw is present at the site, so it may be that this passive education has been sufficient. However, from discussions with the NGO officers (G. James, Pers. Comm), it is their sustained face-to-face conversations (unofficial enforcement) with collectors that has led to collector compliance and the success of the MPA. Enforcement in relation to 'real' structures such as jetties and moorings is also relatively easy as all parties are clear 
about what is protected. In addition, protection for shore-user safety and the possibility of litigation due to property damage may be much stronger deterrents than protection for conservation.

At Fareham Creek the SNCO has been in force since 2003/4 and whilst it was not possible to compare activity prior to the SNCO, it is clear that it is not preventing collection. This would seem to be a flagrant breach of the rules, however, the SNCO only prohibits commercial collection. It is impossible to distinguish between collection for commercial and personal use (the impacts are also not different), but the site history, the long period of time some collectors spent at the site (over two hours) and personal observations by the authors all support the view that regular commercial collection is extremely likely. Signage has been placed at Fareham Creek, but in contrast to Dell Quay there is no sustained official or unofficial enforcement. The MPA at Fareham Creek has, therefore, effectively been unforced since its inception.

The absence of collectors at Pagham Harbour during the two recording periods precludes any discussion on the management effectiveness. The wardens have reported a small number of non-permitted collectors ( $R$. Carver, Pers. Comm.) suggesting that the rules are not being adhered to by some. It is not clear if this applies to permitted collectors, although it might be expected that their willingness to pay for a permit would mean they are willing to follow the general MPA rules.

\subsection{Does education change stakeholder behaviour?}

The production of the Bait Collectors' Code was a recommendation of the public enquiry established for the MPA at Fareham Creek and distributed in 2003/4. It is significant to see that the vast majority of the angling stores still recognise the code after nearly ten years, especially in the absence of recent promotion. It is clear that the majority of shops (and the collectors who supply them) are following the code indicating that this method of education has been successful over a considerable period of time. Nevertheless, many of the shops stated that certain groups were not following the code (especially in relation to back-filling holes). The difficulty of reaching all relevant stakeholders with limited resources is a key issue for the leaflet approach considering the disparate groups of people involved; a lack of affiliation of many to any recognised organisation [15] and the nomadic nature of some collectors who travel around the country. Unless all stakeholder types are reached by passive educational methods the capacity for changing behaviour is very limited.

As the majority of those stakeholders questioned stated they follow the code it would seem leaflet production is a successful method of education. However, to be successful education should induce a change in the behaviour to meet the objectives underpinning the management policy. Nearly all of the baitspecific points in Table 1 are standard practice for experienced collectors. Restating standard methods is likely to explain why the majority said they follow the code. Stakeholder involvement is an important way 
of stimulating support, a sense of ownership and buy-in to conservation projects (see references cited in Cooke et al. [10]), but if the influence of those with a vested interest is too great when developing the educational information then the status quo will be maintained. It was originally thought that back-filling of holes is also the easiest method to dig over sediment (G. Watson, Pers. Obser.) suggesting that the code is restating standard collector practice for this too. However, our data show that $100 \%$ of the observed collectors from both sites were not back-filling, supporting the statements of survey respondents. Therefore, in two of the most popular sites in the UK a lack of compliance (no back-filling) is the norm.

\subsection{Does local marine conservation work?}

Pressey et al. [28] state that local actions, which are typically not guided by regional designs [20], have two advantages for conservation. Firstly, they are motivated and supported by the people directly affected [34] and secondly, they can be based on detailed information on biodiversity and socio-economic variables [6]. However, our empirical data have shown that these schemes will fail unless a number of general 'rules' for local marine conservation management are followed.

An effective MPA incorporates well-designed planning [22] so any local management approach must also be underpinned by robust, site-specific evidence of the level of impact. For example the bag limits, permitting and zonation for Pagham Harbour is excessive when compared with the very low levels of bait collection recorded. The implementation of the appropriate level and extent of management should match the actual (not perceived) pressure. The ad hoc way management methods were established and the fact that it was several years before these were evaluated highlights a common problem of MPA management [27]. Local management methods, and MPAs generally, must be established with scientific evaluation and assessment integrated from the start. Ultimately this will provide the data for evidence-based management, but the relatively high costs (time and monetary) compared to the establishment and designation may be very difficult for local management groups to cover.

The differences between the three geographically close sites confirm that any management must be sitespecific and tailored to the local needs. Regional/national level management is important for displacement issues, giving parity between regional governing organisations and simplifying the process, but one size will not fit all. The size of the region, accessibility of alternative sites, densities of target species as well as many other factors will determine the level of potential displacement from a site once management methods are implemented. Local management methods and MPAs must be drawn up to account for these issues, but linked to a regional approach [28].

Enforcement is critical to any MPA management (either voluntary or backed by statute) (e.g. [18], [8] and [10]) and the local management of bait collection is no exception. Without enforcement MPAs often create social friction; increasing the risk that the public may dismiss them [14]. Comparisons between Dell Quay 
and Fareham Creek and the evaluation of the Bait Collectors' code show that enforcement should be through people. Signage, leaflets and other unsupported passive mechanisms are ineffective in ensuring that the rules are adhered to. An alternative approach for enforcement would be to use CBNRM (Community Based Natural Resource Management). This is a common method in reef conservation, but for this to be successful the community should be identifiable and have unambiguous 'ownership/stewardship' of the protected resource [31]. For temperate MPAs (mainly located in developed countries) the stakeholders that represent the 'community' are often not obvious, especially those established in multistakeholder areas with competing requirements and diverse pressures e.g. European Marine Sites and the new MCZs in the UK. Often, the 'communities' also lack the capacity to undertake adequate enforcement in the face of infringements [41]. Reliance on the bait collectors to be involved in managing the resource is also unrealistic as they have low community capacity and social capital due to: (a) the disparate groups of people involved; (b) a lack of affiliation of many to any recognised organisation [15] and (c) the nomadic nature of some collectors. This inevitably leads to a lack of coordination and co-operation needed to solve social dilemmas [31]. Ultimately, CBNRM is not going to be suitable for bait collection or many other activities in multi-stakeholder coastal MPAs leaving the compliance issue unresolved.

Using technology to address the issues of enforcement and compliance is currently a hot topic in marine conservation and management. For example, a recent meeting at Google Ltd's headquarters was specifically on ocean surveillance (MPA [25]). Systems including passive acoustics to vessel tracking were suggested, however, coastal areas preclude many of these methods. For example, intertidal harvesting is often on foot, but even if using small vessels those less than $12 \mathrm{~m}$ and operating within EU member states are currently exempt from Vessel Monitoring Systems (Council Regulation, 1224/2009). Excessive signal to noise ratios of busy coastal areas are also likely to hinder an acoustic approach. CCTV is now an everyday part of many people's lives and the step-change in technology (motion tracking/facial recognition; cheap, build your own Unmanned Aerial Vehicles [UAVs]) and reduction in price mean these could offer a costeffective solution for NGOs managing many inshore activities, obviating the need for community involvement in enforcement. These methods are especially effective for activities which occur in remote places or at any time of day or night e.g. bait collection. Appropriate CCTV and UAV systems are available now, although privacy legislation issues and general public acceptance of this 'surveillance conservation' need to be urgently resolved.

Reliance on relatively 'cheap' passive educational approaches is the hallmark of local conservation, but as has been shown for the Bait Collectors' Code they lack the 'educational teeth' to move stakeholders towards change. An information leaflet does increase knowledge of a subject (e.g. [2] and [12]), but alone it does not translate to actual changes in behaviour (e.g. [7] and [35]). Environmental education should not simply be one-way communication; instead it should include dialogue and be participatory and extensive [39] with considerable thought given to the content of any disseminated information [1]. A number of 
environmental interventions to engage the public in conservation strategies have been put forward [9] and [10], but just as evaluation should be integral to MPA design, so ancillary educational approaches must also be assessed (e.g. [21]). Only then will the true value of MPA education be known.

MPAs continue to be established in developed countries through national or trans-national legislation, but many delivery organisations have insufficient resources for establishing and maintaining appropriate management systems. Combining these economic challenges with the promotion of stakeholder involvement means that MPAs that are small in extent, local in their management and have associated educational methods to change behaviour are likely to be preferred by governments in to the future. The data presented here for bait collection has shown these relatively cheap locally-driven conservation methods do have the power to deliver effective management of our marine resources now and for the future, but as with all MPAs, only if the golden rules are followed.

\section{Acknowledgements}

Gordon Watson acknowledges the financial support of the Crown Estate and Natural England as well as the additional support of the EU Interreg IVa Chronexpo project and the Nuffield Foundation. The authors would also like to thank Y. Guler, R. Shipway and C. Sherhod for the collection and processing of the samples. This project would not have been possible without the help of Residents 1 and 2 and the assistance of the wardens at each site.

\section{References}

[1] C. Abraham, L. Southby, S. Quandte, B. Krahe, W. van der Sluijs. What's in a leaflet? Identifying researchbased persuasive messages in European alcohol-education leaflets. Psychol Health, 22 (2007), pp. 31-60

[2] A. Al-Asfour, L. Andersson. The effect of a leaflet given to parents for first aid measures after tooth avulsion. Dent Traumatol, 24 (2008), pp. 515-521

[3] W.G. Ambrose, M. Dawson, C. Gailey, P. Ledkovsky, S. O'Leary, B. Tassinari, et al. Effects of baitworm digging on the soft-shelled clam (Mya arenaria) in Maine: shell damage and exposure on the sediment surface. J Shellfish Res, 17 (1998), pp. 1043-1049

[4] S.C. Anderson, J. Mills-Flemming, R. Watson, K.K. Lotze. Rapid global expansion of invertebrate fisheries: trends, drivers and ecosystem effects. PLoS One, 6 (2011), p. E14735

[5] M. Armstrong, A. Brown, J. Hargreaves, K. Hyder, S. Pilgrim-Morrison, M. Munday, et al.

Sea angling 2012-a survey of recreational sea angling activity and economic value in England. Department of Environment Food and Rural Affairs report, UK (2012) 
[6] S. Aswani, M. Lauer. Incorporating fishermen's local knowledge and behaviour into geographical information systems (GIS) for designing marine protected areas in Oceania. Hum Org, 65 (2006), pp. 81-102

[7] P.C. Carré, N. Roche, F. Neukirch, T. Radeau, T. Perez, P. Terrioux, et al. The effect of an information leaflet upon knowledge and awareness of COPD in potential sufferers. Respiration, 76 (2008), pp. 53-60

[8] G. Ceccherelli, A. Pais, S. Pinna, N. Sechi, L.A. Chessa. Human impact on Paracentrotus lividus: the result of harvest restrictions and accessibility of locations. Mar Biol, 158 (2011), pp. 845-852

[9] S.J. Cooke, N.W.R. Lapointe, E.G. Martins, J.D. Thiem, G.D. Raby, M.K. Taylor, et al. Failure to engage the public in issues related to inland fishes and fisheries: strategies for building public and political will to promote meaningful conservation. J Fish Biol, 83 (2013), pp. 997-1018

[10] S.J. Cooke, C.D. Suski, R. Arlinghaus, A.J. Danychuk. Voluntary institutions and behaviours as alternatives to formal regulations in recreational fisheries management. Fish Fish, 14 (2013), pp. 439-457

[11] T.H.A. Cunha, H. Queiroga. Estimation of the Diopatra neopolitana annual harvest resulting from bait digging activity in Canal de Mira, Ria de Aveiro. Fish Res, 76 (2005), pp. 56-66

[12] M.G. Dawes, J. Kacorowski, G. Swanson, J. Hickey, T. Karwalajtys. The effect of a patient education booklet and BP 'tracker' on knowledge about hypertension. A randomized controlled trial. Fam Pract, 27 (2010), pp. 472-478

[13] G.J. Edgar, R.D. Stuart-Smith, T.J. Willis, S. Kininmonth, S.C. Baker, S. Banks, et al. Global conservation outcomes depend on marine protected areas with five key features. Nature, 506 (2014), pp. 216-220

[14] P.B. Fenberg, J.E. Caselle, J. Clauet, M. Clemence, S.D. Gaines, J.A. Garcia-Charton, et al. The science of European marine reserves: status, efficacy and future needs. Mar Policy, 36 (2012), pp. 1012-1021

[15] Fowler SL. Guidelines for managing the collection of bait and other shoreline animals within UK marine Special Areas of Conservation. English Nature report, UK; 1999.

[16] Fowler SL. Investigation into the extent of bait collection and its impacts on features of conservation interest for birds and intertidal species and habitats within the Solent Natural Area. English Nature report, UK; 2001. 
[17] K. Grorud-Colvert, S.E. Lester, S. Airame, E. Neeley, S.D. Gaines. Communicating marine reserve science to diverse audiences. Proc Natl Acad Sci Biol, 107 (2010), pp. 18306-18311

[18] P. Guidetti, M. Milazzo, S. Bussotti, A. Molinari, M. Murenu, A. Pais, et al. Italian marine reserve effectiveness: does enforcement matter? Biol Conserv, 141 (2008), pp. 699-709

[19] Jones PJS, Quiu W, De Santo EM. Governing marine protected areas: getting the balance right. Technical report, United Nations Environment Programme; 2011.

[20] A.T. Knight, R.M. Cowling, M. Rouget, A. Balmford, A.T. Lombard, B.M. Campbell. Knowing but not doing: selecting priority conservation areas and the research-implementation gap. Conserv Biol, 22 (2008), pp. 610-617

[21] C. Leisher, S. Mangubhai, S. Hess, H. Widodo, T. Soekirman, S. Tjoe, et al. Measuring the benefits and costs of community education and outreach in marine protected areas. Mar Policy, 36 (2012), pp. 10051011

[22] C.J. Lundquist, E. Granek. Strategies for successful marine conservation: integrating socioeconomic, political and scientific factors. Conserv Biol, 19 (2005), pp. 1771-1778

[23] S. Marinesque, D.M. Kaplan, L.D. Rodwell. Global implementation of marine protected areas: is the developing world being left behind? Mar Policy, 36 (2012), pp. 727-737

[24] G.M. Martins, S.R. Jenkins, S.J. Hawkins, A.I. Neto, A.R. Medeiros, R.C. Thompson. Illegal harvesting affects the success of fishing closure areas. J Mar Biol Assoc UK, 91 (2011), pp. 929-937

[25] News MPA. Innovative ideas in enforcement: what the future MPA surveillance could look (and even sound) like $15 ; 2014,1-2$

[26] P.J.W. Olive. Polychaeta as a world resource: a review of patterns of exploitation as sea angling baits and the potential for aquaculture based production. Mém Mus natn Hist nat, 162 (1994), pp. 603-610

[27] P.E. Parnell, P.K. Dayton, C. Lennert-Cody, L.L. Rasmussen, J.J. Leichter. Marine reserve design: optimal size, habitats, species affinities, diversity and ocean microclimate. Ecol Appl, 16 (2006), pp. 945-962

[28] R.L. Pressey, M. Mills, R. Weeks, J.C. Day. The plan of the day: managing the dynamic transition from regional conservation designs to local conservation actions. Biol Conserv, 166 (2013), pp. 155-169 
[29] Prior S. Investigating the use of voluntary marine management in the protection of UK marine biodiversity. Report to the Royal Society for the Protection of Birds, Sandy, UK; 2011.

[30] T. Roberts, P.J.S. Jones. Shell-fishing, eider ducks and nature conservation on the Wash: questions raised by a fractured partnership. Soc Nat Resour, 22 (2009), pp. 538-553

[31] M.A. Rudd, M.H. Tupper, H. Folmer, G.C. van Kooten. Policy analysis for tropical marine reserves: challenges and directions. Fish Fish, 4 (2003), pp. 65-85

[32] E. Sala, E. Ballesrtos, P. Denrinos, A. Di Franco, F. Ferretti, D. Foley, et al. The structure of Mediterranean rocky reef ecosystems across environmental and human gradients, and conservation impacts. PLoS One, 7 (2012), p. e32742

[33] P.C.F. Shepherd, J.S. Boates. Effects of a commercial baitworm harvest on semi-palmated sandpipers and their prey in the Bay of Fundy hemispheric shorebird reserve. Conserv Biol, 13 (1999), pp. 347-356

[34] R.J. Smith, D. Verissimo, N. Leader-Williams, R.M. Cowling, A.T. Knight. Let the locals lead. Nature, 462 (2009), pp. 280-281

[35] K. Stamatiou, A. Skolarikos, I. Heretis, V. Papadimitriou, A. Alevizos, G. llias, et al. Does educational printed material manage to change compliance with prostate cancer screening? World J Urol, 26 (2008), pp. 365-373

[36] E. Sypitkowski, C. Bohlen, W.G. Ambrose Jr. Estimating the frequency and extent of bloodworm digging in Maine from aerial photography. Fish Res, 101 (2010), pp. 87-93

[37] R.J. Toonen, T.A. Wilhelm, S.M. Maxwell, D. Wagner, B.W. Bowen, C.R.C. Sheppard, et al. One size does not fit all: the emerging frontier in large-scale marine conservation. Mar Pollut Bull, 77 (2013), pp. 710

[38] G.J. Watson, P. Farrell, S. Stanton, L.C. Skidmore. The effects of bait collection on Nereis virens populations and macrofaunal communities in the Solent, UK. J Mar Biol Assoc UK, 87 (2007), pp. 703-716

[39] J. Wilsdon, R. Willis. See-through science: why public engagement needs to move upstream Demos, London (2004) 
[40] L.J. Wood, L. Fish, J. Laughren, D. Pauly. Assessing progress towards global marine protection targets: shortfalls in information and action. Oryx, 42 (2008), pp. 340-351

[41] S.C.A. Ferse, M. Máñez Costa, K. Schwerdtner Máñez, D.S. Adhuri, M. Glaser. Allies, not aliens: increasing the role of local communities in marine protected area implementation. Environ Conserv, 37 (2010), pp. 23-34 